\title{
ANALYSIS OF DRY SLIDING WEAR BEHAVIOUR OF AL 6061- COCONUT SHELL ASH METAL MATRIX COMPOSITES USING STIR CASTING
}

\author{
Original scientific paper
}

UDC: 669.717:621.746

https://doi.org/10.18485/aeletters.2019.4.2.3

\author{
Kolusu Varalakshmi ${ }^{1 *}$, K.Ch. Kishore Kumar ${ }^{1}$, A. Jawahar Babu ${ }^{1}$ \\ ${ }^{1}$ Gudlavalleru Engineering College, Gudlavalleru, India-521356
}

\begin{abstract}
:
Al6061 with hard particle reinforcement contains higher stiffness, maximum strength and wear resistance when compare to unreinforced alloy. They can be usage for self-propelled automotive components and aircraft construction. Metal matrix composite (MMC) concentrate chiefly on amended specific strength and wear resistance application. Aluminium as base material and coconut shell ash(CSA) as reinforcement has good potential. The principle difficult is to create this composite in a practical manner. In this project Al6061-CSAp castings with different volume fraction of CSA were produced in an argon atmosphere by an enhanced stir casting method. We found that with more \% of CSA addition there is an
\end{abstract}

\section{ARTICLE HISTORY}

Received: 05.03.2019.

Accepted: 17.06.2019.

Available: 30.06.2019.

\section{KEYWORDS}

Al 6061, coconut shell ash (CSA), Mechanical Properties, Wear, Taguchi method, Stir Casting

\section{INTRODUCTION}

A Composite material can be formed by combining two or more dissimilar materials together. The mechanical properties of the composites will be better than the individual components. The composite materials will be composed of two or more phases. They are matrix phase and reinforcement phase [1].

The metal is the major part and the minor constituents are reinforcements may be in the form of particles, whiskers, continuous and discontinuous fibres. The reinforcement material may be a ceramic or organic in nature. MMC consists of superior mechanical, physical and electrical properties. Hybrid composite consists of more than two constituting materials [4]. Aluminium Matrix Composites are extensively used due to their desirable superior properties. The applications are diversified in production, thermal, marine and automobile industries like marine, aircrafts, automobiles, electrical wires and household utensils. T.Nithyanandhan, K.Rohith, C.G Sidharath, C.Sachin, Sarayu Jagadesh investigated the mechanical behaviour of Aluminium metal matrix hybrid composite containing $\mathrm{B}_{4} \mathrm{C} \&$ coconut shell ash as reinforcement at various percentage. The hardness, tensile strength is decreases slightly than base metal [2]. P.B Madakson, D.S.Yawas and A. Apasi, was made an attempt to investigate the characteristics of coconut shell ash. The microscopic analysis reveals that element like $\mathrm{SiO}_{2}$, $\mathrm{Al}_{2} \mathrm{O}_{3}, \mathrm{MgO}$ and $\mathrm{Fe}_{2} \mathrm{O}_{3}$ as major constituents and hard in nature leads to its utilization in automobile applications. As coconut shell ash has high thermal stability with low density, can be used in producing composite products with good thermal resistance. [6-8]. 
P. Lakshmi Kanthan, Dr. B. Prabu, focused on synthesis and determination of mechanical and tribological properties of aluminium alloy Al6061Coconut Shell Ash (CSA). It is observed that 6\% CSA reinforced composite has the maximum tensile strength, maximum hardness and minimum wear [9].

The current state, demands towards development of engineering material to various specific problems in an exertion to overcome the challenge in manufacturing via tools and materials. Metal Matrix Composites (MMCs) bring significant profit due to attainable properties are prominent for the components concerned [10]. The number of metallic alloys employed industrially is very high and new composition is being tested for employed to meet new diversify demands of many industries. Moreover, the innumerable alloys, aluminium alloy find the wide application in industrial and technology due to as high strength - weight ratio, specific modulus, and high wear resistance. Precisely, Aluminium Metal Matrix Composites (AMC) are effectively implemented in few industrial applications like aerospace, automotive, defence, and electronic packing $[12,13]$.

\section{SELECTION OF MATERIALS}

\subsection{Preparation of Coconut Shell Ash}

Coconut shells is collected and dried in sun for 7 days. The burned out is crushed in a jaw crusher and ball mill respectively to get fine particles [3]. The powder is exposed to an argon gas at $1150^{\circ} \mathrm{C}$ for 3 hours. The ash is further grinded in a ball mill and is screened to a fine size of 200 mesh $(\approx 45 \mu \mathrm{m})$ to use as reinforced particles. The chemical composition of Al6061 alloy and CSA presented in Table 1 and Table 2 respectively.

Table 1. Chemical Composition of Al 6061

\begin{tabular}{|c|c|c|c|c|}
\hline Element & $\mathrm{Mg}$ & $\mathrm{Si}$ & $\mathrm{Fe}$ & $\mathrm{Cu}$ \\
\hline $\begin{array}{c}\text { Weight } \\
\%\end{array}$ & 1.08 & 0.63 & 0.17 & 0.32 \\
\hline $\mathrm{Cr}$ & $\mathrm{Zn}$ & $\mathrm{Mn}$ & Others & $\mathrm{Al}$ \\
\hline 0.014 & 0.25 & 0.52 & 0.05 & remaining \\
\hline
\end{tabular}

Table 2. Chemical Composition of CSA

\begin{tabular}{|c|c|c|c|c|}
\hline Element & $\mathrm{Al}_{2} \mathrm{O}_{3}$ & $\mathrm{Fe}_{2} \mathrm{O}_{3}$ & $\mathrm{CaO}$ & $\mathrm{K}_{2} \mathrm{O}$ \\
\hline $\begin{array}{c}\text { Weight } \\
\%\end{array}$ & 15.6 & 12.4 & 0.57 & 0.52 \\
\hline $\mathrm{MgO}$ & $\mathrm{Na}_{2} \mathrm{O}$ & $\mathrm{MnO}$ & $\mathrm{Si}_{2} \mathrm{O}$ & $\mathrm{Al}$ \\
\hline 16.2 & 0.45 & 0.22 & 45.05 & 0.3 \\
\hline
\end{tabular}

\section{EXPRIMENTAL WORK}

\subsection{Methodology}

Al6061 alloy of $1.5 \mathrm{~kg}$ was placed in stir casting machine to heat up to $750^{\circ} \mathrm{C}$, along with $1.0 \mathrm{wt}$. \% preheated flux, and wt.\% reinforcement at $300^{\circ} \mathrm{C}$ in an oven. Argon gas envirnment is provided to avoid oxidation. Preheated flux was added to the melt and allowed for homogenization for 5-6 $\mathrm{min}$ by agitating of stirrer in the melt. After removal of slag from the surface, preheated (up to $300^{\circ} \mathrm{C}$ ) CSA particles were added into the vortex of the melt during stirring.[5] The mixture is allowed to stir at $600 \mathrm{rpm}$ for $10 \mathrm{~min}$. The melt is allowed into a two finger die of $270 \mathrm{~mm}$ length and $22 \mathrm{~mm}$ diameter while stirring. The same process is repeated for reinforcement $3 \%$ and $5 \%$. The ingots with and without reinforcement composites are subjected to a heat treatment for $24 \mathrm{hrs}$ at $110^{\circ} \mathrm{C}$ in muffle furnace for homogenation. Compositions of Composites shown in Table 3.

Table 3. Compositions of Composites

\begin{tabular}{|c|c|c|c|}
\hline $\begin{array}{c}\text { Specimen. } \\
\text { No }\end{array}$ & Composition & $\begin{array}{c}\text { Al6061 } \\
\text { Wt\% }\end{array}$ & $\begin{array}{l}\mathrm{CSA} \\
\mathrm{Wt} \% \\
\end{array}$ \\
\hline C1 & Al 6061 & 100 & 0 \\
\hline $\mathrm{C} 2$ & $\begin{array}{c}\text { Al } 6061+\text { CSA } \\
(1 \%)\end{array}$ & 99 & 1 \\
\hline C3 & $\begin{array}{c}\text { Al } 6061+\text { CSA } \\
(2 \%)\end{array}$ & 98 & 2 \\
\hline C4 & $\begin{array}{c}\text { Al } 6061+\text { CSA } \\
(3 \%)\end{array}$ & 97 & 3 \\
\hline C5 & $\begin{array}{c}\text { Al } 6061+\text { CSA } \\
(4 \%)\end{array}$ & 96 & 4 \\
\hline C6 & $\begin{array}{c}\text { Al } 6061+\text { CSA } \\
(5 \%)\end{array}$ & 95 & 5 \\
\hline C7 & $\begin{array}{c}\text { Al } 6061+\text { CSA } \\
(6 \%)\end{array}$ & 94 & 6 \\
\hline
\end{tabular}

\section{RESULTS AND DISCUSSION}

\subsection{Density}

The particle density of CSA determined was $2.05 \mathrm{~g} / \mathrm{cm}^{3}$ while the density of the Al6061 alloy was $2.67 \mathrm{~g} / \mathrm{cm}^{3}$. Since CSA has lower density than Al6061 alloy, its addition to the composite will make the density of the composite to be less than that of the alloy [11]. The density of composite at various proportions is discussed in Table 4 which are decreased with increase in percentage of reinforcement. Comparisiton of densities are shown in Fig.1. 
Table 4. Comparison of Densities

\begin{tabular}{|c|c|c|c|}
\hline S. No & Composition & $\begin{array}{c}\text { Theoretical } \\
\text { Density } \\
(\mathrm{g} / \mathrm{cc})\end{array}$ & $\begin{array}{c}\text { Experimental } \\
\text { Desnity } \\
(\mathrm{g} / \mathrm{cc})\end{array}$ \\
\hline 1 & $\mathrm{C} 1$ & 2.700 & 2.700 \\
\hline 2 & $\mathrm{C} 2$ & 2.690 & 2.640 \\
\hline 3 & $\mathrm{C} 3$ & 2.686 & 2.620 \\
\hline 4 & $\mathrm{C} 4$ & 2.680 & 2.610 \\
\hline 5 & $\mathrm{C} 5$ & 2.674 & 2.590 \\
\hline 6 & $\mathrm{C} 6$ & 2.667 & 2.580 \\
\hline 7 & $\mathrm{C} 7$ & 2.661 & 2.570 \\
\hline
\end{tabular}

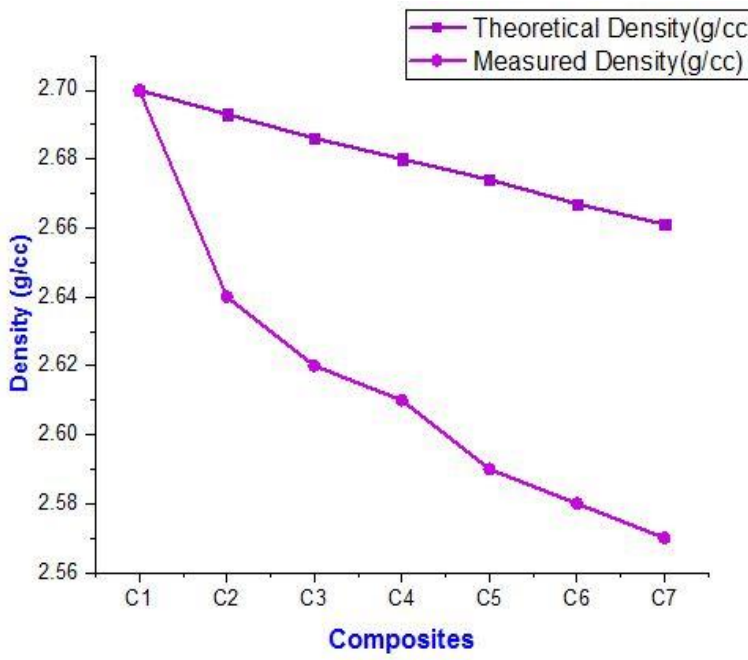

Fig.1 Comparision of Densities

\subsection{Porosity Measurement}

The Porosity of the metal matrix composites presented in Table 5.

Table 5. Porosity Measurement

\begin{tabular}{|c|c|c|c|c|}
\hline $\begin{array}{c}\text { S. } \\
\text { No }\end{array}$ & Sample & $\begin{array}{c}\text { The } \\
\text { Density } \\
(\mathrm{g} / \mathrm{cc})\end{array}$ & $\begin{array}{c}\text { Meas } \\
\text { Density } \\
(\mathrm{g} / \mathrm{cc})\end{array}$ & $\begin{array}{c}\text { \%Porosity } \\
((\text { The-Meas)/The) } \\
* 100\end{array}$ \\
\hline 1 & $\mathrm{C} 1$ & 2.700 & 2.700 & 0.00 \\
\hline 2 & $\mathrm{C} 2$ & 2.690 & 2.640 & 1.86 \\
\hline 3 & $\mathrm{C} 3$ & 2.686 & 2.620 & 2.46 \\
\hline 4 & $\mathrm{C} 4$ & 2.680 & 2.610 & 2.61 \\
\hline 5 & $\mathrm{C} 5$ & 2.674 & 2.590 & 3.14 \\
\hline 6 & $\mathrm{C} 6$ & 2.667 & 2.580 & 2.51 \\
\hline 7 & $\mathrm{C} 6$ & 2.661 & 2.570 & 2.61 \\
\hline
\end{tabular}

\subsection{Micro Vickers Hardness}

The hardness of the composite is determined by using Vickers micro harness tester [14]. The micro hardness of composites is increases for $C_{1}$ to $\mathrm{C}_{7}$ as shown in Fig.2. The increase in hardness is due to the present of hard particles in the reinforcement.

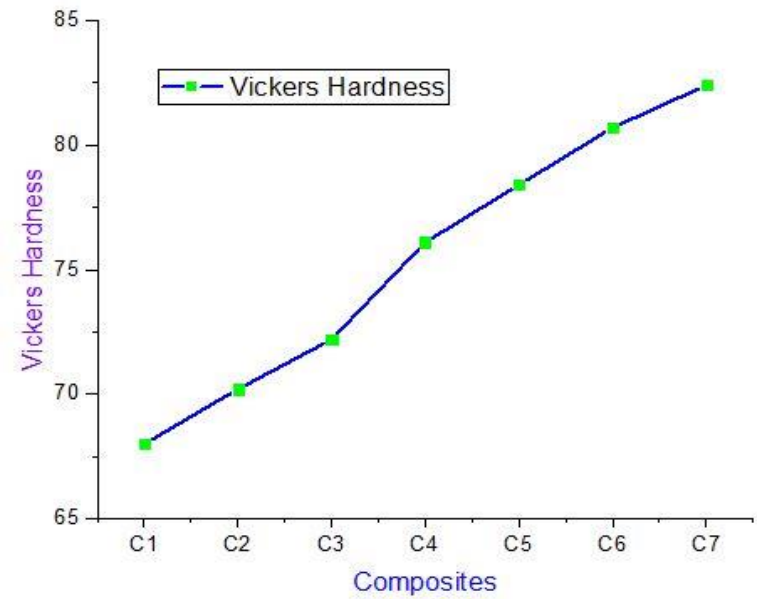

Fig.2 Variation of Vickers Hardness Number

\subsection{Tensile behaviour of Al 6061 with CSA}

Tensile strength of the composite is determined with ASTM E8 (Fig.3) specimen using universal testing machine. Tensile strength of the composite from $C_{1}$ to $C_{7}$ is as shown in Fig.4. The strength of the composite is found to be increasing with an increase in addition of reinforcement [15]. The maximum tensile stress obtained was $143.66 \mathrm{MPa}$ for $C_{7}$ composites.

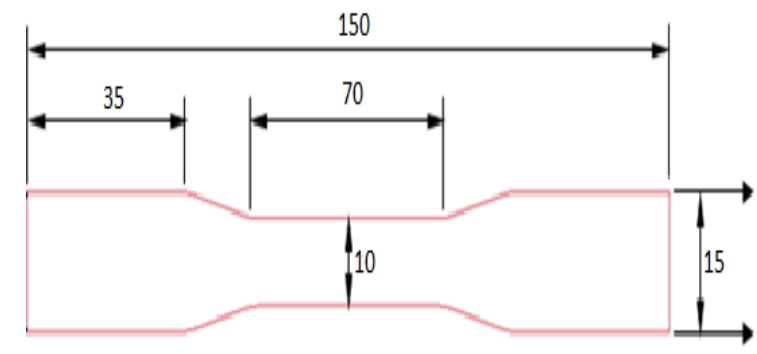

Fig.3. ASTM E8 Specimen

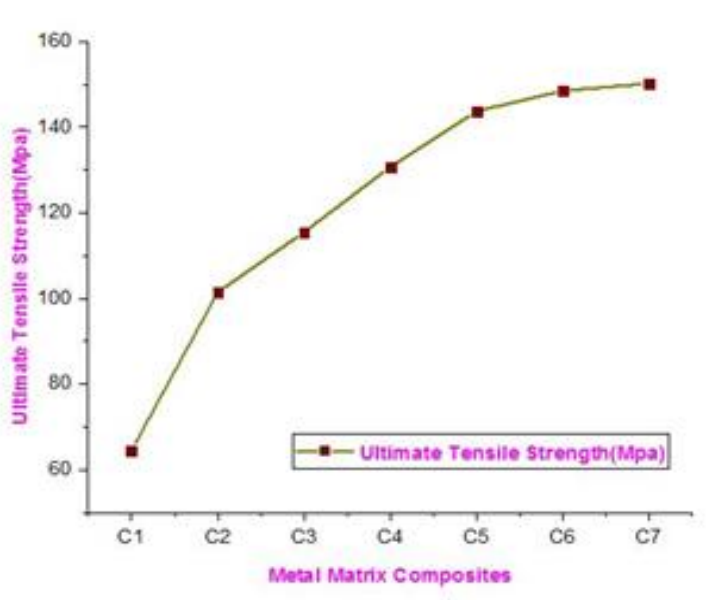

Fig.4. Variation of Ultimate Tensile Stress(Mpa) 


\subsection{Wear Analysis (Taguchi method)}

The wear behaviour of the composite is determined by using Pin on Disc wear tester with the ASTM G99 standard specimen. The objective of the experimental plan is to calculate the important factors and combination of factors affecting the wear process to achieve the minimum wear rate and coefficient of friction. The experiments were performed on an orthogonal array, with the objective of the effect of sliding speed, applied load and sliding distance. The specified input parameters along with their levels are shown in Table 6 . The designs of experiments are shown in Table $(7,8,11,14)$ shows the experimental results average of two repetitions for wear rate and coefficient of friction. The ranking of process parameters using signal to noise ratios obtained for different parameter levels for wear rate and coefficient of friction are given in Table $(9,12,15)$ and Table $(10,13,16)$ respectively for $1 \%, 3 \%$ \& 5\% reinforced CSA MMCs.
Table 6. Process Parameters and levels

\begin{tabular}{|c|c|c|c|}
\hline Level & Load $(\mathrm{N})$ & $\begin{array}{c}\text { Sliding } \\
\text { Speed,S (m/s) }\end{array}$ & $\begin{array}{c}\text { Sliding } \\
\text { Distance, } \mathrm{D}(\mathrm{m})\end{array}$ \\
\hline 1 & 15 & 0.5 & 500 \\
\hline 2 & 25 & 1.0 & 750 \\
\hline 3 & 35 & 1.5 & 1000 \\
\hline
\end{tabular}

Table 7. Orthogonal array L9 of Taguchi

\begin{tabular}{|c|c|c|c|}
\hline Exp No. & Column 1 & Column 2 & Column 3 \\
\hline 1 & 15 & 0.5 & 500 \\
\hline 2 & 15 & 1.0 & 750 \\
\hline 3 & 15 & 1.5 & 1000 \\
\hline 4 & 25 & 0.5 & 500 \\
\hline 5 & 25 & 1.0 & 750 \\
\hline 6 & 25 & 1.5 & 1000 \\
\hline 7 & 35 & 0.5 & 500 \\
\hline 8 & 35 & 1.0 & 750 \\
\hline 9 & 35 & 1.5 & 1000 \\
\hline
\end{tabular}

Table 8. Results of L9 Orthogonal array for Al - 6061 / 1\% CSA

\begin{tabular}{|c|c|c|c|c|c|c|c|}
\hline S No. & $\begin{array}{c}\mathrm{L} \\
(\mathrm{N})\end{array}$ & $\begin{array}{c}\mathrm{S} \\
(\mathrm{m} / \mathrm{s})\end{array}$ & $\begin{array}{c}\mathrm{D} \\
(\mathrm{m})\end{array}$ & COF & $\begin{array}{c}\text { Wear rate } \\
\left(\mathrm{mm}^{3} / \mathrm{m}\right)\end{array}$ & S/N ratio c.o.f & S/N ratio wear rate \\
\hline 1 & 15 & 0.5 & 500 & 0.4867 & 0.0043 & 6.255 & 47.33 \\
\hline 2 & 15 & 1.0 & 750 & 0.3533 & 0.0062 & 9.036 & 44.15 \\
\hline 3 & 15 & 1.5 & 1000 & 0.3267 & 0.0076 & 9.717 & 42.38 \\
\hline 4 & 25 & 0.5 & 500 & 0.3720 & 0.0095 & 8.589 & 40.45 \\
\hline 5 & 25 & 1.0 & 750 & 0.3480 & 0.00101 & 9.168 & 59.91 \\
\hline 6 & 25 & 1.5 & 1000 & 0.3200 & 0.00148 & 9.897 & 56.59 \\
\hline 7 & 35 & 0.5 & 500 & 0.3371 & 0.0082 & 9.443 & 41.72 \\
\hline 8 & 35 & 1.0 & 750 & 0.2971 & 0.00114 & 10.54 & 58.86 \\
\hline 9 & 35 & 1.5 & 1000 & 0.2600 & 0.00168 & 11.70 & 55.49 \\
\hline
\end{tabular}

Table 9. Responses table for $\mathrm{S} / \mathrm{N}$ ratio for wear (1\%CSA)

\begin{tabular}{|c|c|c|c|}
\hline Level & Load & Sliding Velocity & Distance \\
\hline 1 & 44.62 & 43.17 & 54.26 \\
\hline 2 & 52.32 & 54.31 & 46.70 \\
\hline 3 & 52.03 & 51.49 & 48.01 \\
\hline Delta & 7.70 & 11.14 & 7.57 \\
\hline Rank & 2 & 1 & 3 \\
\hline
\end{tabular}

Table 10. Responses table for $\mathrm{S} / \mathrm{N}$ ratio for coefficient of friction (1\% CSA)

\begin{tabular}{|c|c|c|c|}
\hline Level & Load & Sliding Velocity & Distance \\
\hline 1 & 8.337 & 8.096 & 8.898 \\
\hline 2 & 9.218 & 9.582 & 9.775 \\
\hline 3 & 10.562 & 10.438 & 9.443 \\
\hline Delta & 2.225 & 2.342 & 0.878 \\
\hline Rank & 2 & 1 & 3 \\
\hline
\end{tabular}

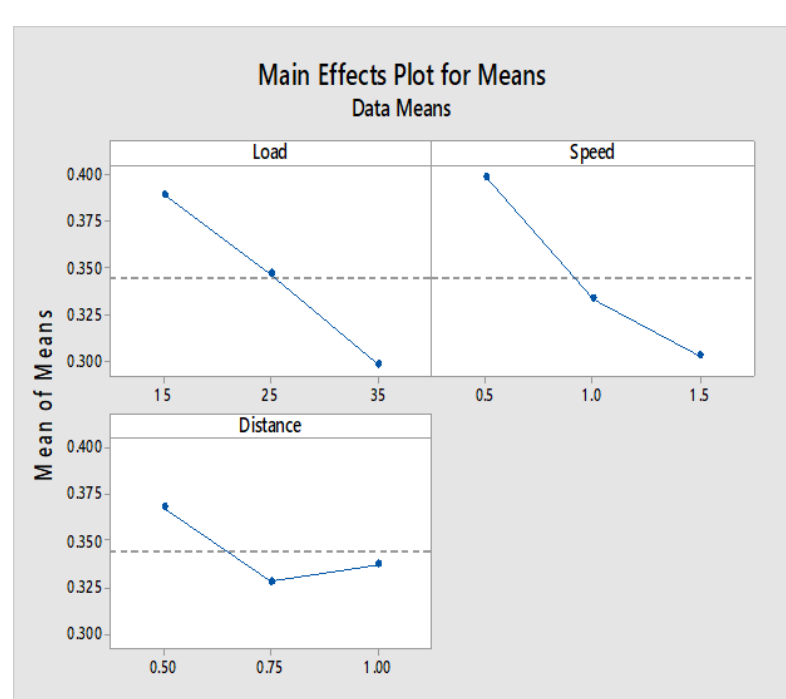

Fig.5. Main effects for plot for Means -Coefficient of Friction(1\% CSA) 


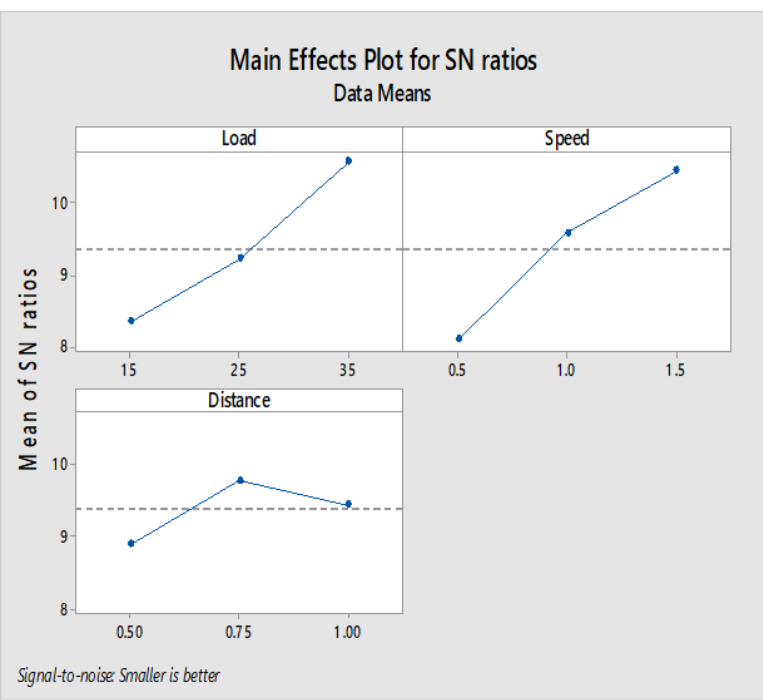

Fig.6. Main effects for plot for S/N Ratios - Coefficient of Friction (1\% CSA)

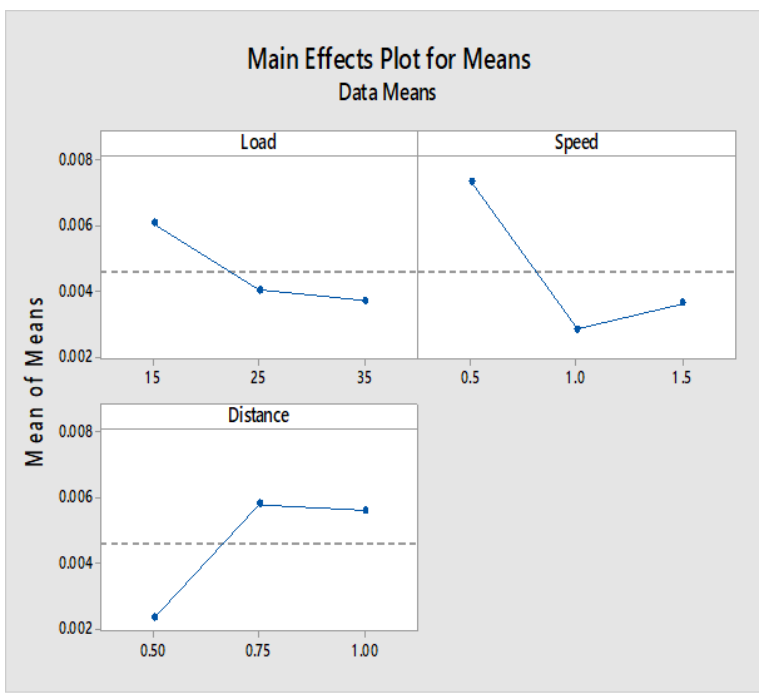

Fig.7. Main effects for plot for Means -Wear Rate $(1 \% \mathrm{CSA})$

Table 11. Results of L9 Orthogonal array for Al - 6061 / 3\% CSA

\begin{tabular}{|c|c|c|c|c|c|c|c|}
\hline S No & $\begin{array}{c}\mathrm{L} \\
(\mathrm{N})\end{array}$ & $\begin{array}{c}\mathrm{S} \\
(\mathrm{m} / \mathrm{s})\end{array}$ & $\begin{array}{c}\mathrm{D} \\
(\mathrm{m})\end{array}$ & COF & $\begin{array}{c}\text { Wear rate } \\
\left(\mathrm{mm}^{3} / \mathrm{m}\right)\end{array}$ & $\begin{array}{c}\text { S/N ratio } \\
\text { c.o.f }\end{array}$ & S/N ratio wear rate \\
\hline 1 & 15 & 0.5 & 500 & 0.4467 & 0.0040 & 7.000 & 47.958 \\
\hline 2 & 15 & 1.0 & 750 & 0.3667 & 0.0055 & 8.714 & 45.192 \\
\hline 3 & 15 & 1.5 & 1000 & 0.3867 & 0.0050 & 8.253 & 46.020 \\
\hline 4 & 25 & 0.5 & 500 & 0.3680 & 0.0041 & 8.683 & 47.744 \\
\hline 5 & 25 & 1.0 & 750 & 0.3440 & 0.0087 & 9.268 & 41.209 \\
\hline 6 & 25 & 1.5 & 1000 & 0.3400 & 0.00138 & 9.370 & 57.202 \\
\hline 7 & 35 & 0.5 & 500 & 0.2314 & 0.0056 & 12.711 & 45.036 \\
\hline 8 & 35 & 1.0 & 750 & 0.0857 & 0.00123 & 21.338 & 58.201 \\
\hline 9 & 35 & 1.5 & 1000 & 0.3743 & 0.00115 & 8.5359 & 58.786 \\
\hline
\end{tabular}

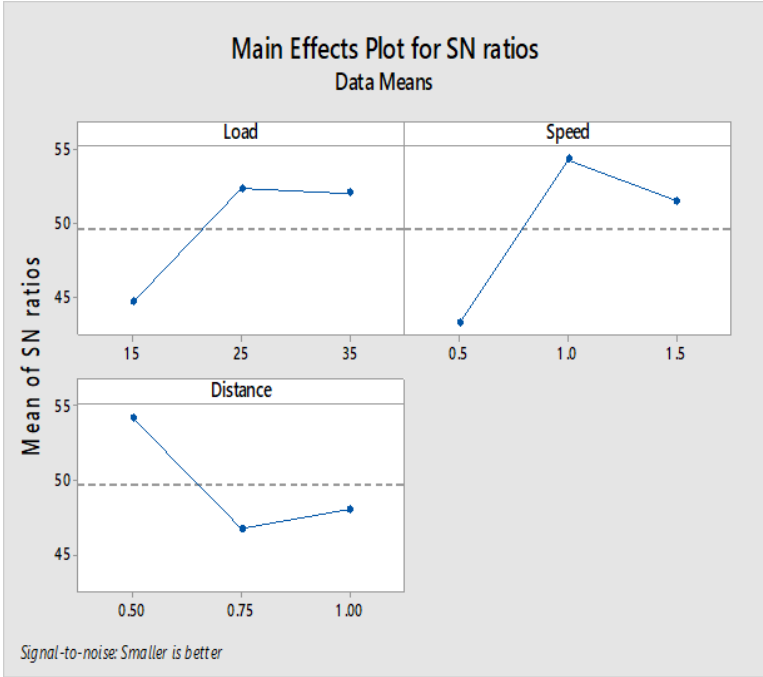

Fig.8. Main effects for plot for S/N Ratio -Wear Rate (1\%CSA)

Fig.5-8 shows Main effects for Means and $\mathrm{S} / \mathrm{N}$ ratio plots for $1 \%$ influence of process parameters on wear rate and coefficient of friction graphically.
Table 12. Responses table for $\mathrm{S} / \mathrm{N}$ ratio for wear $(3 \%$ CSA)

\begin{tabular}{|c|c|c|c|}
\hline Level & Load & Sliding Velocity & Distance \\
\hline 1 & 46.39 & 46.91 & 54.45 \\
\hline 2 & 48.72 & 48.20 & 50.57 \\
\hline 3 & 54.01 & 54.00 & 44.09 \\
\hline Delta & 7.62 & 7.09 & 10.37 \\
\hline Rank & 2 & 3 & 1 \\
\hline
\end{tabular}

Table 13. Responses table for $\mathrm{S} / \mathrm{N}$ ratio for coefficient of friction (3\% CSA)

\begin{tabular}{|c|c|c|c|}
\hline Level & Load & Sliding Velocity & Distance \\
\hline 1 & 7.989 & 9.465 & 12.570 \\
\hline 2 & 9.107 & 13.107 & 8.645 \\
\hline 3 & 14.196 & 8.720 & 10.078 \\
\hline Delta & 6.206 & 4.388 & 3.925 \\
\hline Rank & 1 & 2 & 3 \\
\hline
\end{tabular}

Fig.9-12 shows Main effects for Means and S/N ratio plots for $3 \%$ influence of process parameters on wear rate and coefficient of friction graphically. 


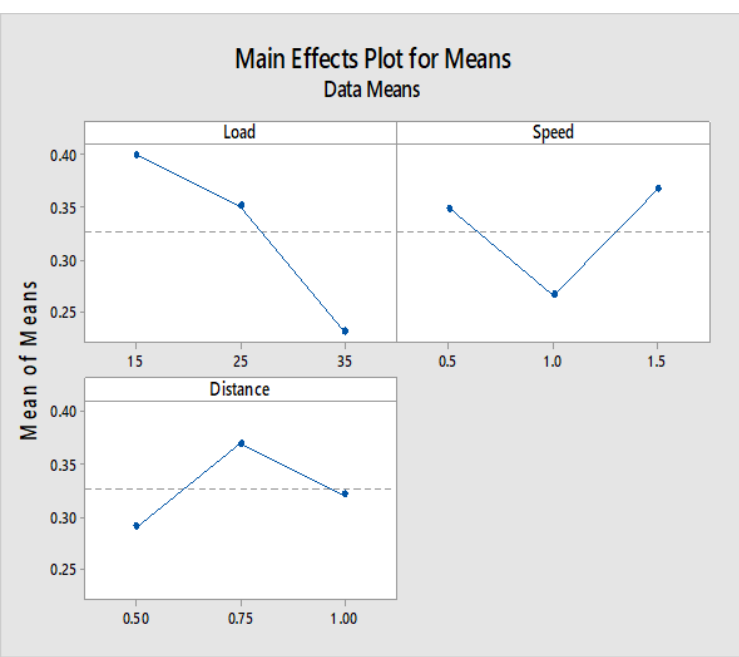

Fig.9. Main effects for plot for Means -Coefficient of Friction(3\% CSA)

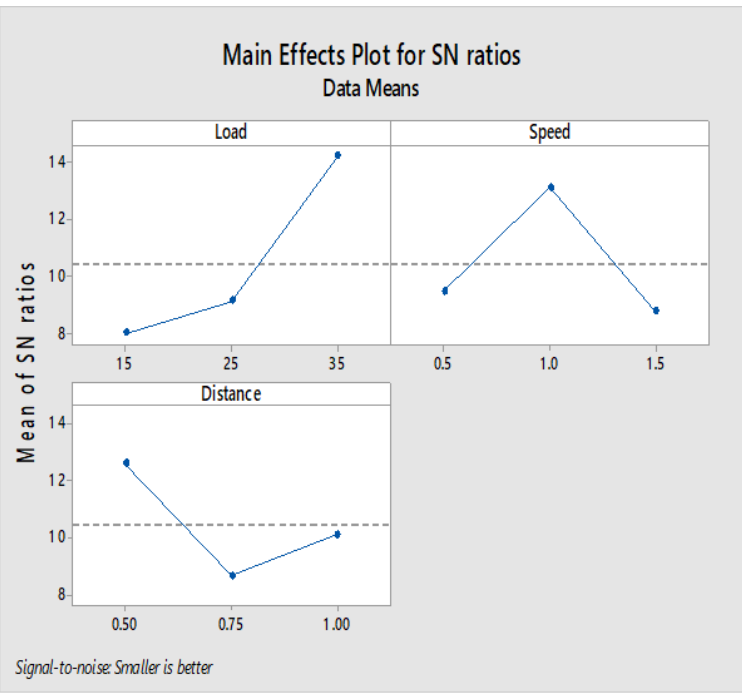

Fig.10. Main effects for plot for S/N Ratios -Coefficient of Friction ( $3 \%$ CSA)

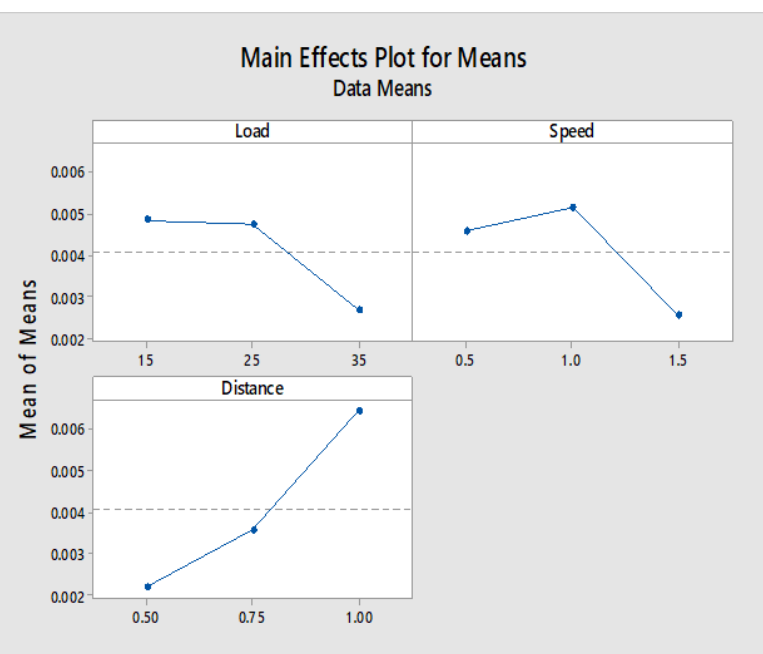

Fig.11. Main effects for plot for Means - Wear Rate (3\% CSA)

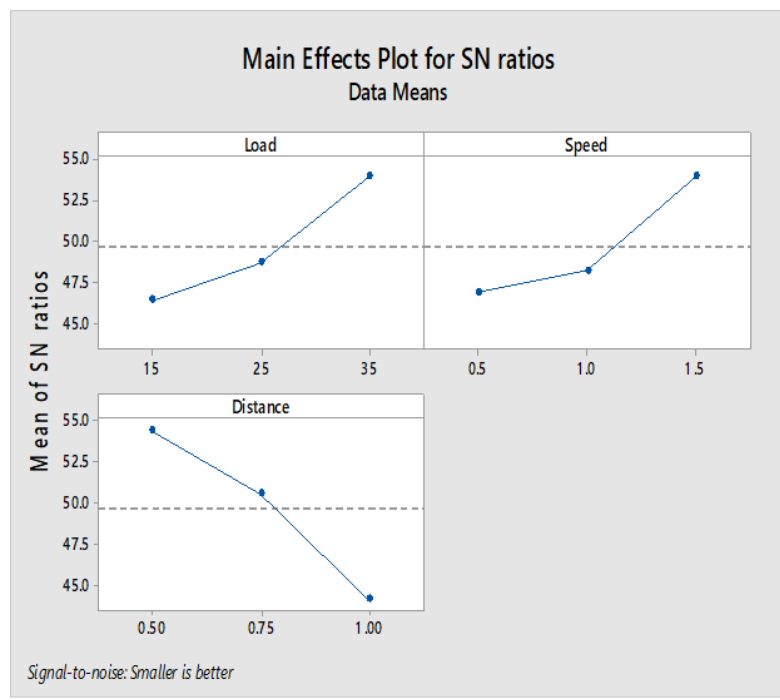

Fig.12. Main effects for plot for S/N Ratio - Wear Rate(3\% CSA)

Table 14. Results of L9 Orthogonal array for Al - 6061 / 5\% CSA

\begin{tabular}{|c|c|c|c|c|c|c|c|}
\hline S No. & $\begin{array}{c}\mathrm{L} \\
(\mathrm{N})\end{array}$ & $\begin{array}{c}\mathrm{S} \\
(\mathrm{m} / \mathrm{s})\end{array}$ & $\begin{array}{c}\mathrm{D} \\
(\mathrm{m})\end{array}$ & COF & $\begin{array}{c}\text { Wear rate } \\
\left(\mathrm{mm}^{3} / \mathrm{m}\right)\end{array}$ & S/N ratio c.o.f & S/N ratio wear rate \\
\hline 1 & 15 & 0.5 & 500 & 0.4733 & 0.0051 & 6.4967 & 45.8486 \\
\hline 2 & 15 & 1.0 & 750 & 0.3667 & 0.0083 & 8.7146 & 41.6184 \\
\hline 3 & 15 & 1.5 & 1000 & 0.3600 & 0.0093 & 8.8739 & 40.6303 \\
\hline 4 & 25 & 0.5 & 500 & 0.3240 & 0.0033 & 9.7891 & 49.6297 \\
\hline 5 & 25 & 1.0 & 750 & 0.3920 & 0.0095 & 8.1343 & 40.4455 \\
\hline 6 & 25 & 1.5 & 1000 & 0.3480 & 0.0068 & 9.1684 & 43.3498 \\
\hline 7 & 35 & 0.5 & 500 & 0.4429 & 0.0043 & 7.0747 & 47.3306 \\
\hline 8 & 35 & 1.0 & 750 & 0.1486 & 0.0015 & 16.561 & 56.4782 \\
\hline 9 & 35 & 1.5 & 1000 & 0.2829 & 0.0067 & 10.968 & 43.4785 \\
\hline
\end{tabular}

Table 15. Responses table for $\mathrm{S} / \mathrm{N}$ ratio for wear(5\%CSA)

\begin{tabular}{|c|c|c|c|}
\hline Level & Load & Sliding Velocity & Distance \\
\hline 1 & 42.70 & 47.60 & 48.56 \\
\hline 2 & 44.48 & 46.18 & 44.91 \\
\hline 3 & 49.10 & 42.49 & 42.80 \\
\hline Delta & 6.40 & 5.12 & 5.76 \\
\hline Rank & 1 & 3 & 2 \\
\hline
\end{tabular}

Table 16. Responses table for $\mathrm{S} / \mathrm{N}$ ratio for coefficient of friction (5\% CSA)

\begin{tabular}{|c|c|c|c|}
\hline Level & Load & Sliding Velocity & Distance \\
\hline 1 & 8.028 & 7.787 & 10.742 \\
\hline 2 & 9.031 & 11.137 & 9.824 \\
\hline 3 & 11.535 & 9.670 & 8.028 \\
\hline Delta & 3.506 & 3.350 & 2.714 \\
\hline Rank & 1 & 2 & 3 \\
\hline
\end{tabular}


Fig.13-16 shows Main effects for Means and $\mathrm{S} / \mathrm{N}$ ratio plots for $5 \%$ influence of process parameters on wear rate and coefficient of friction graphically.

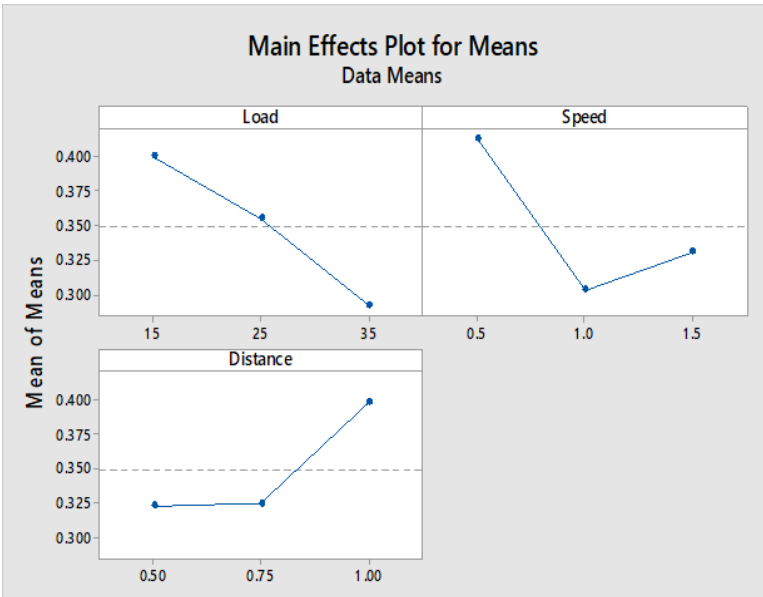

Fig.13. Main effects for plot for Means - Wear Rate $(5 \%$ CSA)

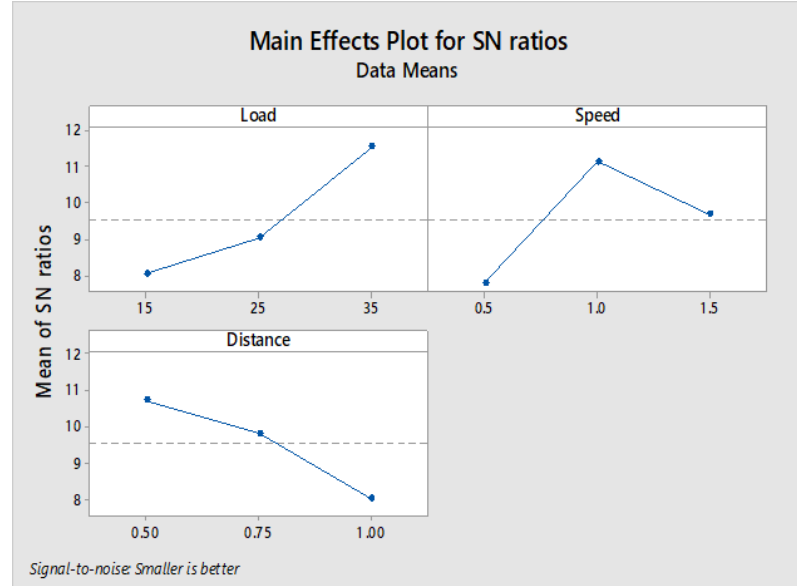

Fig.14. Main effects for plot for S/N Ratios - Coefficient of Friction(5\% CSA)

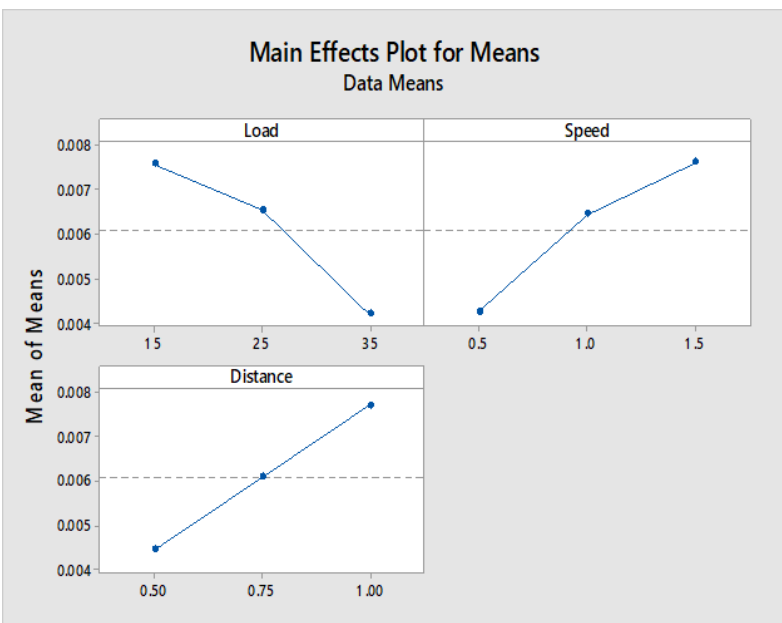

Fig.15. Main effects for plot for Means -Wear Rate(5\% CSA)

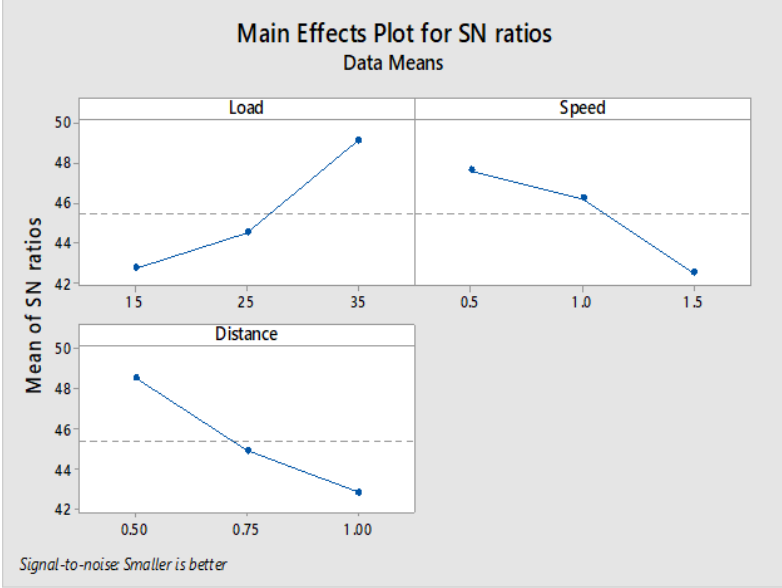

Fig.16. Main effects for plot for S/N Ratios -Coefficient of Friction

\subsection{Analysis of variance (ANOVA)}

ANOVA is a method of portioning changeability into some source of disparity and the related degree of freedom in experimentation. This analysis was carried out for a level of significance of $5 \%$, i.e., for $95 \%$ a level of confidence. Table $(17,18)$, Table $(19,20)$ and Table $(21,22)$ shows $1 \%, 3 \%$ \& $5 \%$ respectively CSA MMCs of the ANOVA results for wear rate and coefficient of friction for three factors varied at three levels and interactions of those factors.

It can be observed that for CSA ( $1 \%, 3 \%$ \& $5 \%)$ Composites, from the Table 17 and 22, that the sliding distance has the highest influence on wear rate.

Hence sliding distance is an important control factor to be taken into consideration during wear process followed by applied loads respectively.

From the analysis of variance $\& \mathrm{~S} / \mathrm{N}$ ratio, it is inferred that the sliding distance has the highest contribution on wear rate \& coefficient of friction followed by load $\&$ sliding speed. 
Table 17. Analysis of Variance for Means (Wear Rate) (1\% CSA)

\begin{tabular}{|c|c|c|c|c|c|c|}
\hline Source & DF & Seq SS & Adj SS & Adj MS & F & P \\
\hline Load & 2 & 0.000010 & 0.000010 & 0.000005 & 0.42 & 0.705 \\
\hline Speed & 2 & 0.000035 & 0.000035 & 0.000018 & 1.51 & 0.399 \\
\hline Distance & 2 & 0.000023 & 0.000023 & 0.000012 & 0.98 & 0.504 \\
\hline Residual Error & 2 & 0.000023 & 0.000023 & 0.000012 & & \\
\hline Total & 8 & 0.000092 & & & & \\
\hline
\end{tabular}

Table 18. Analysis of Variance for Means (Coefficient of Friction) (1\% CSA)

\begin{tabular}{|c|c|c|c|c|c|c|}
\hline Source & DF & Seq SS & Adj SS & Adj MS & F & P \\
\hline Load & 2 & 0.012385 & 0.012385 & 0.006193 & 6.53 & 0.133 \\
\hline Speed & 2 & 0.014553 & 0.014553 & 0.007276 & 7.67 & 0.115 \\
\hline Distance & 2 & 0.002578 & 0.002578 & 0.001289 & 1.36 & 0.424 \\
\hline Residual Error & 2 & 0.001897 & 0.001897 & 0.000949 & & \\
\hline Total & 8 & 0.031413 & & & & \\
\hline
\end{tabular}

Table 19. Analysis of Variance for Means (Wear Rate) (3\% CSA)

\begin{tabular}{|c|c|c|c|c|c|c|}
\hline Source & DF & Seq SS & Adj SS & Adj MS & F & P \\
\hline Load & 2 & 0.000009 & 0.000009 & 0.000005 & 4.29 & 0.189 \\
\hline Speed & 2 & 0.000011 & 0.000011 & 0.000006 & 5.48 & 0.154 \\
\hline Distance & 2 & 0.000028 & 0.000028 & 0.000014 & 13.30 & 0.070 \\
\hline Residual Error & 2 & 0.000002 & 0.000002 & 0.000001 & & \\
\hline Total & 8 & 0.000051 & & & & \\
\hline
\end{tabular}

Table 20. Analysis of Variance for Means (Coefficient of Friction) (3\% CSA)

\begin{tabular}{|c|c|c|c|c|c|c|}
\hline Source & DF & Seq SS & Adj SS & Adj MS & F & P \\
\hline Load & 2 & 0.045618 & 0.045618 & 0.022809 & 2.47 & 0.288 \\
\hline Speed & 2 & 0.017570 & 0.017570 & 0.008785 & 0.95 & 0.513 \\
\hline Distance & 2 & 0.009509 & 0.009509 & 0.004755 & 0.51 & 0.660 \\
\hline Residual Error & 2 & 0.018484 & 0.018484 & 0.009242 & & \\
\hline Total & 8 & 0.091181 & & & & \\
\hline
\end{tabular}

Table 21. Analysis of Variance for Means (Wear Rate) (5\% CSA)

\begin{tabular}{|c|c|c|c|c|c|c|}
\hline Source & DF & Seq SS & Adj SS & Adj MS & F & P \\
\hline Load & 2 & 0.000018 & 0.000018 & 0.000009 & 1.96 & 0.337 \\
\hline Speed & 2 & 0.000018 & 0.000018 & 0.000009 & 1.89 & 0.346 \\
\hline Distance & 2 & 0.000016 & 0.000016 & 0.000008 & 1.69 & 0.372 \\
\hline Residual Error & 2 & 0.000009 & 0.000009 & 0.000005 & & \\
\hline Total & 8 & 0.000061 & & & & \\
\hline
\end{tabular}

Table 22. Analysis of Variance for Means (Coefficient of Friction) (5\% CSA)

\begin{tabular}{|c|c|c|c|c|c|c|}
\hline Source & DF & Seq SS & Adj SS & Adj MS & F & P \\
\hline Load & 2 & 0.0178 & 0.0178 & 0.00892 & 0.78 & 0.561 \\
\hline Speed & 2 & 0.0200 & 0.0200 & 0.01000 & 0.88 & 0.533 \\
\hline Distance & 2 & 0.0110 & 0.0110 & 0.00553 & 0.49 & 0.673 \\
\hline Residual Error & 2 & 0.0228 & 0.0228 & 0.01140 & & \\
\hline Total & 8 & 0.0717 & & & & \\
\hline
\end{tabular}




\section{SEM AND EDS INVESTIGATIONS}

Fig.17-20 illustrates SEM images of the metal matrix composites. As shown in (Fig.17), the 0 wt. $\%$ of coconut shell ash display a fractured area, indicating smooth surface but in the 1 wt. \% coconut shell ash composite, there are toughening mechanisms cause of CSA particle like deboning and crack deflection. It can be seen these mechanisms in (Fig.18). In addition to this, fracture surface of 3wt.\% (Fig.19) coconut shell ash composite has large plastic deformation areas. So, it can be easily understand that why adding coconut shell ash to improve the strength and strain of composite materials. The $5 \mathrm{wt}$.\% of CSA shown in in Fig.20.

SEM and EDS for the composites are considered for microscopic analysis, at the interface (Fig.2124) shows the presence of elements such as $C, M g$, $\mathrm{Al}, \mathrm{Si}, \mathrm{Ca}$, and $\mathrm{Fe}$. Grain sizes decreases, due to pinning effect at the grain boundary. Fine grain size of composite contributes to strength by Orowan Mechanism. Average sizes of grains measured for composites from $C_{1}$ to $C_{4}$ are $46,35,28$ and $16 \mu \mathrm{m}$.

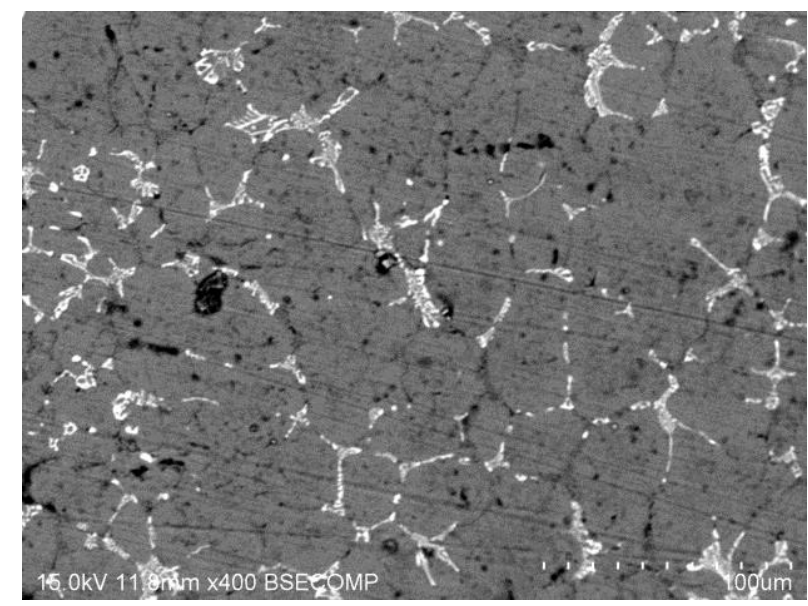

Fig. 17. The SEM of Al 6061

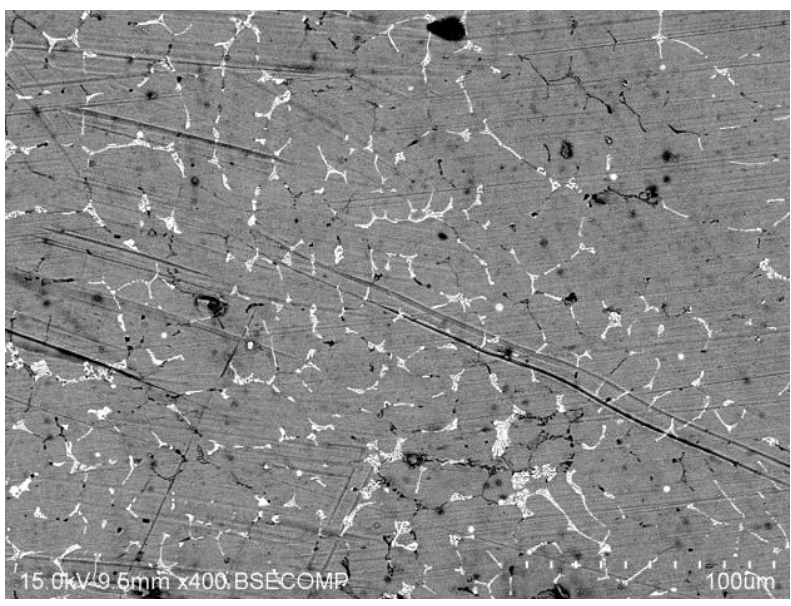

Fig.18. The SEM of $1 \%$ CSA

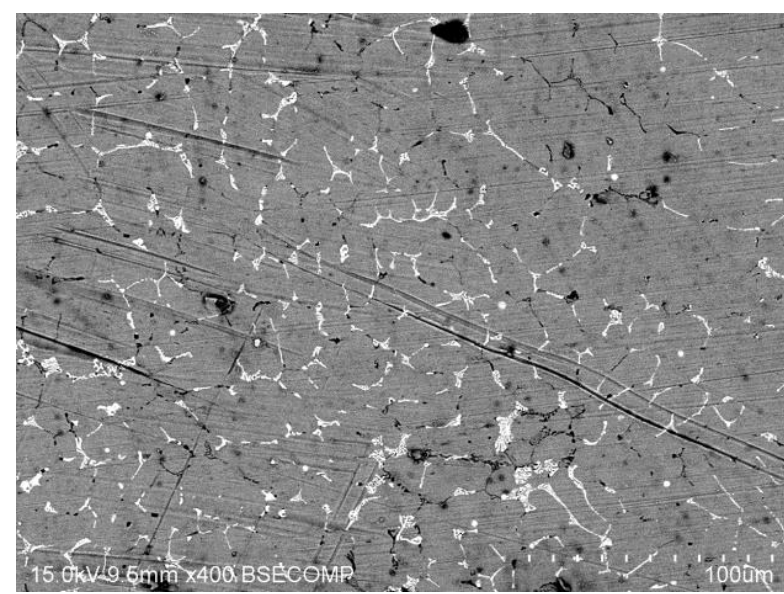

Fig.19. The SEM of 3\% CSA

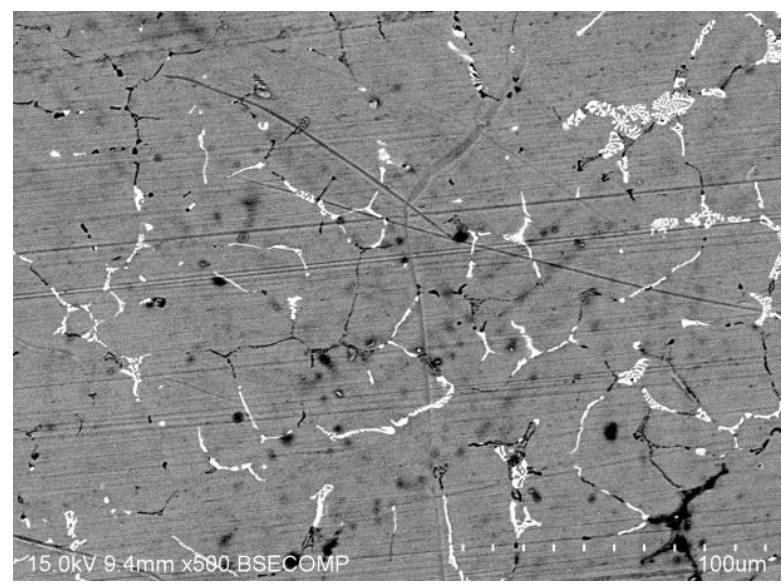

Fig.20. The SEM of $5 \%$ CSA

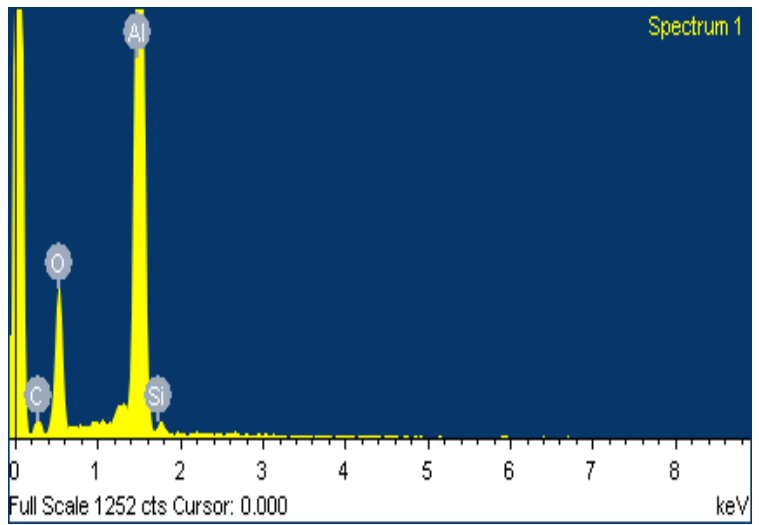

Fig.21. EDS spectrum of Al6061

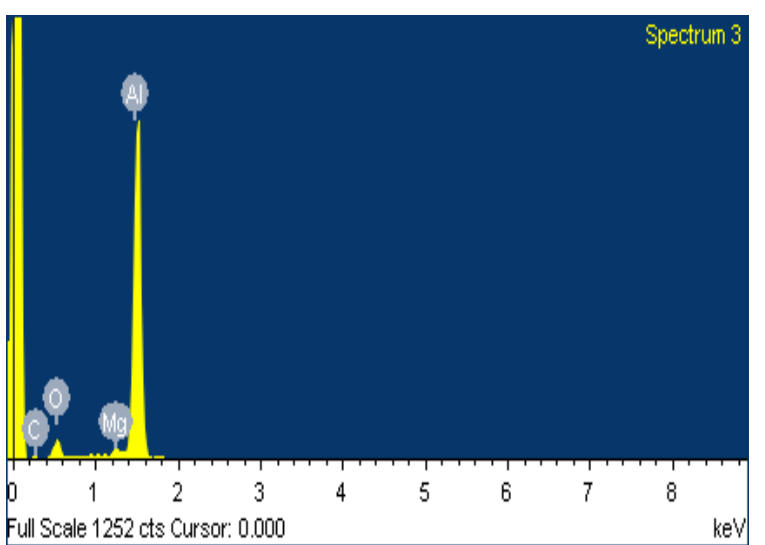

Fig.22. EDS spectrum $1 \%$ CSA 


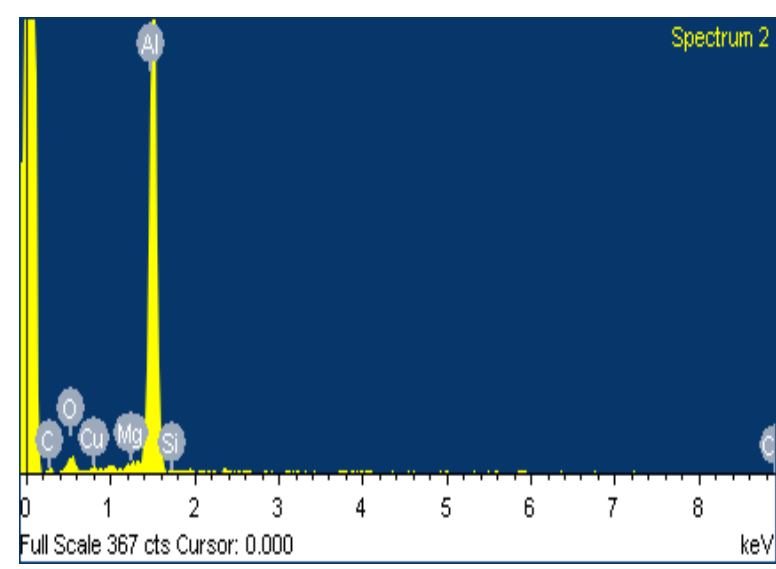

Fig.23. EDS spectrum of $3 \%$ CSA

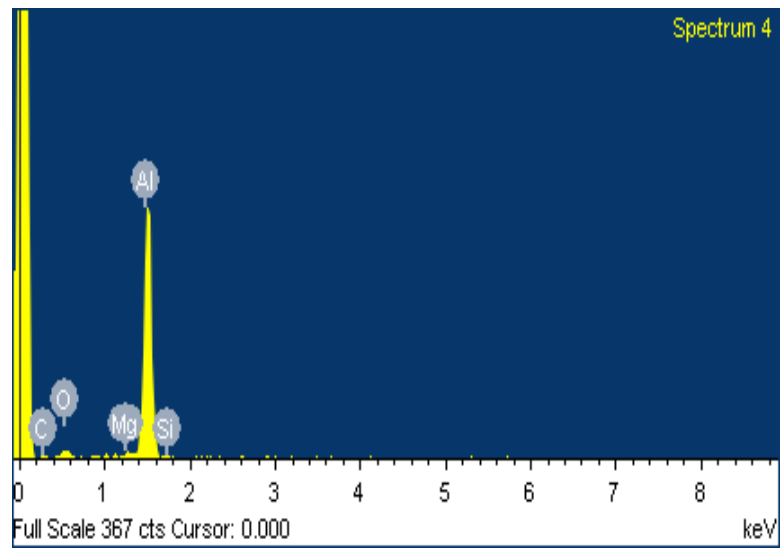

Fig.24. EDS spectrum of $5 \%$ CSA

\section{CONCLUSION}

The following conclusions have been drawn:

1. The optimum conditions of the production process were that the pouring temperature was $700 \circ \mathrm{C}$, preheated mold temperature was $350 \circ \mathrm{C}$, the stirring speed was $600 \mathrm{rev} / \mathrm{min}$, the stirring time after the completion of particle feeding was $5 \mathrm{~min}$, the particle addition rate was $5 \mathrm{~g} / \mathrm{min}$.

2. The density of the composites produced with only CSA as reinforcements showed an decreasing trend with the increase of the content of the reinforcements.

3. With the increase of the content of ash in the mix, the hardness increases. Similarly, the introduction of ceramic particles also increases the hardness of the composites because they act as the load bearing elements in the produced.

4. The Ultimate Tensile Strength of the composites increased with trivial with the increase of percentage of Coconut Shell Ash.

\section{REFERENCES}

[1] R. Siva Sankara Raju, M.K. Panigrahi, R.I. Ganguly, G. Srinivasa Rao, Tribological behaviour of al-1100-coconut shell ash (CSA) composite at elevated temperature. Tribology International, 129, 2019: 55-66.

https://doi.org/10.1016/i.triboint.2018.08.011

[2] T. Nithyanandhan, K. Rohith, C.G. Sidharath, C.Sachin, Sarayu Jagadesh, Investigation of Mechanical Properties on Aluminium Based Hybrid Composites. International Journal of Innovative Research in Science, Engineering and Technology, 6 (7), 2017: 118-126.

[3] M. Poornesh, J.X. Saldanha, J. Singh, G.M. Pinto, Gaurav, Effect of Coconut Shell Ash and SiC Particles on Mechanical Properties of Aluminium Based Composites. American Journal of Materials Science, 7(4), 2017: 112115.

https://doi.org/10.5923/i.materials.20170704.09

[4] R. Siva Sankara Raju, M.K. Panigrahi, R.I. Ganguly, G. Srinivasa Rao, Optimization of tribological behavior on Al- coconut shell ash composite at elevated temperature, International Conference on Advances in Metallurgy, Materials and Manufacturing. IOP Publishing, IOP Conf. Series: Materials Science and Engineering 314, 2018: 012009. https://doi.org/10.1088/1757-899X/314/1/012009

[5] R.S.S. Raju, G.S. Rao, Assessment of Tribological performance of Coconut Shell Ash Particle Reinforced Al-Si-Fe Composites using Grey-Fuzzy Approach. Tribology in Industry, 39 (3), 2017: 364-377.

https://doi.org/10.24874/ti.2017.39.03.12

[6] S.S. Raju, G.S. Rao, B.V. Siva, Experimental studies of mechanical properties and tribological behaviour of aluminium composite reinforced with coconut shell ash particulates, Int. J. Materials Engineering Innovation, 9 (2) 2018: 141-157 https://doi.org/10.1504/ijmatei.2018.093812

[7] P.B. Madakson, D.S. Yawasand, A. Apasi, Characterization of Coconut Shell Ash for Potential Utilization in Metal Matrix Composites for Automotive Applications. International Journal of Engineering Science and Technology, 4 (03), 2012: 1190-1198.

[8] P. Lakshmikanthan, Dr. B. Prabu, Mechanical and Tribological behavior of Aluminium Al6061 Coconut shell ash composite using Stir Casting Pellet Method. Journal of the Balkan 
Tribological Association, 22 (4-I), 2016: 40084018.

[9] G. Srinivasa Rao, B. Venkata Siva, S. Sankar Raju, Experimental studies of mechanical properties and tribological behaviour of aluminium composite reinforced with coconut shell ash particulates. International Journal of Materials Engineering Innovation, 9 (2), 2018: 140-157.

https://doi.org/10.1504/JMMATEl.2018.093812

[10] O.O. Daramola, A.A. Adediran, A.T. Fadumiye, Evaluation of the mechanical properties and corrosion behaviour of coconut shell ash reinforced aluminium (6063) alloy composites, Leonardo Electron. J. Pract. Technol., 14 (27), 2015: 107-119.

[11] M. Poornesh, J.X. Saldanha, J. Singh, G.M. Pinto, Effect of Coconut Shell Ash and SiC Particles on Mechanical Properties of Aluminium Based Composites. American Journal of Materials Science, 7 (4), 2017: 112115.

https://doi.org/10.5923/j.materials.20170704.09

[12] R. Siva Sankara Raju, M.K. Panigrahi, R.I. Ganguly, G. Srinivasa Rao, Investigation of Tribological Behavior of a Novel Hybrid
Composite Prepared with Al-Coconut Shell Ash Mixed with Graphite. Metallurgical and Materials Transactions A., 48 (8), 2018: 38923903.

https://doi.org/10.1007/s11661-017-4139-1

[13] J.W. Pinto, G. Sujaykumar, R.M. Sushiledra, Effect of Heat Treatment on Mechanical and Wear Characterization of Coconut Shell Ash and E-glass Fiber Reinforced Aluminum Hybrid Composites. American Journal of Materials Science, 6 (4A), 2016: 15-19.

https://doi.org/10.5923/c.materials.201601.03

[14] S.S. Raju, G.S. Rao, Assessments of Desirability Wear Behaviour on Al-Coconut Shell Ash Metal Matrix Composite using Grey - Fuzzy Reasoning Grade. Indian Journal of Science and Technology, 10 (15), 2017: 1-11. https://doi.org/10.17485/ijst/2017/v10i15/113826

[15] S.R. Rallabandi, G. Srinivasa Rao, Assessment of Tribological Performance of Al-Coconut Shell Ash Particulate-MMCs using GreyFuzzy Approach, J. Inst. Eng. India Ser. C, 100 (1), 2019: 13-22.

https://doi.org/10.1007/s40032-017-0388-4 